\title{
EFFECT OF DIRECT ACTING ANTIVIRAL (SOFOSBUVIR) ON DAILY LIVING ACTIVITIES OF PATIENTS WITH HEPATITIS C VIRUS
}

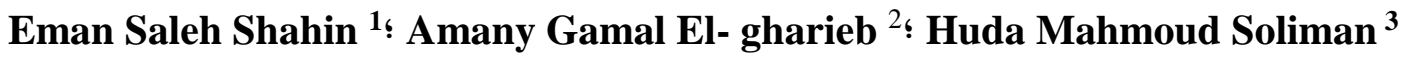 \\ Professor of Medical-Surgical Nursing ${ }^{1}$ \\ Lecturer of Medical-Surgical Nursing ${ }^{2}$ 'Master Degree Medical-Surgical of Nursing ${ }^{3}$ \\ Faculty of Nursing, Port Said University ${ }^{1,2,3}$
}

\begin{abstract}
Background: chronic hepatitis $\mathrm{C}$ virus is a major cause of liver-related morbidity and mortality and is known to impair activities of daily living. Direct-acting antivirals have demonstrated high efficacy to achieve sustained virological response in chronic hepatitis $\mathrm{C}$ patients. Aim :This study aimed to assess effect of direct acting antiviral treatment on daily living activities for patients with hepatitis C virus. Setting :This study conducted at ElMataria Daqahlia Health insurance hospital in El-Mataria city, Daqahlia and EL-Tadamon Hospital in Port -Said city. A descriptive sample of 100 male and female adult patients were included in the study .Tools of data collection: Three tools were used to collect study data. First tool is a questionnaire used to assess patient's demographic data, medical and surgical history, the second tool is care dependency scale used to assess level of patient dependency and third tool was daily living scale to assess daily living activities of the study patients. Results: the study results revealed that the majority of sample $73 \%$ were dependent as an effect of treatment mostly in activities which need more effort or more cognitive abilities as housekeeping and learning ability while $27 \%$ were independent independent mainly in personal activities as continence, getting dressed and undressed. Conclusion. The majority of the sample were nearly independent in personal ADL and physical activities, while about one fourth one- fourth were dependent in other activities which need more effort or more cognitive. Recommendations: Assessment of patient physical, psychological, social and spiritual health behaviors should be a part of routine patient's health assessment. Further study is recommended in a larger sample with considering factors could affecting patient's response to viral hepatitis treatment.
\end{abstract}

Key words: Activities of daily living, Care dependency scale, Direct-acting antivirals, Hepatitis C virus, Patients. 


\section{INTRODUCTION}

Hepatitis C virus is one of Egypt's biggest health problems, Chronic hepatitis is estimated at 71 million people around the world, over 95 percent of people with hepatitis $\mathrm{C}$ infection can be fully recovered within 2-3 months, 1.34 million people died from viral hepatitis in 2015, estimated 325 million people have chronic hepatitis infections globally, a large number of people with chronic infection developing cirrhosis or liver cancer (AbdEllatef \& Mohamed2019).

The National Committee for Control of Viral Hepatitis was formed in Egypt in 2006 and developed the new national strategy for control of HCV. The first strategy for control of HCV was applied in 2008 to 2012. It Included 48 weeks treatment with pegylated interferon in combination with ribavirin. Then, using new treatment program the Ministry of Health initiated the 2014 to 2018 Plan of Action for the Prevention, Care and Treatment of Viral Hepatitis. This program depending on direct-acting antiviral agents which interferes with the HCV lifecycle and restricts viral replication (Tawfeek et al., 2020).

With the use of current new direct acting antivirals, in addition to satisfactory tolerability and high success rates and excellent safety profile of these medications a sustained virological response (SVR) rate >95 percent can be achieved (Ioannou et al., 2018). Hepatitis C virus Combination therapy is generally well tolerated with no specific side-effects of its own; fatigue, headache, nausea, insomnia, depression, weakness and anemia are the most common side-effects found. Although, this side effect with interferonfree regimens is less serious (Dusheiko, 2017). Liver structure and prognosis directly affected by the treatment of $\mathrm{HCV}$ and measuring these parameters objectively are possible. Besides this, there is also a change in subjective parameters, such as the quality of life and activities of daily living (Kesen et al.,2019).

Therefore, Hepatitis C virus infection and its treatment can affect the physical, social, psychological, and emotional well-being of the patients, subjective and objective findings should be recorded. In addition, HCV and its treatment may influence appetite, sleep and cause pain and fatigue that ultimately interferes the ability of patients to perform daily living activities (Crusse \& Kent 2015). In nursing, the concept of daily living activities is important because nurses are mostly responsible for the maintenance and/ or enhancement of daily living activities. Nurses must determine the ability of a patient to perform activities either physical or mental in the sense of patients baseline functional status (Abdelsalam, 2016). 
The nurses are playing a crucial role in the recovery process as which should be closed to the patients and their families during all process of the disease. As a part of the health system the unique role of nurses in caring for people, sick or well, is to determine their responses to their health status and to assist them in caring out those activities contributing to health or recovery that they would undertake unassisted if they had the requisite power, will, or knowledge to do so in such a way as to help them gain full of partial independence as rapidly as possible. So, they are performing this role through continuous monitoring and evaluation before, during and after treatment in order to ensure compliance with the medication regimen and overall care plan (Zwakhalen et ai.,2018). Therefore, the current study aims to assess effect of direct acting antiviral treatment (sofosbuvir) on daily living activities of patients with hepatitis c virus.

\section{Significance of the study:}

Sofosbuvir a recent medication used in Egypt as an antiviral medication that prevents hepatitis $\mathrm{C}$ virus. A whole new era in which the treatment paradigm went from daily injections to once-daily pills and from one-year course to as short as 12 weeks with much improved safety profile and response rates that are approaching $100 \%$ in some cases. On the other hand, sofosbuvir medication could cause side effect if it is not used appropriately with considering specific precautions and treatment regimen. Moreover, there are no enough studies about it in Egypt yet; therefore, it is crucial and urgent need to assess sofosbuvir adverse effects on daily living activities for patients taking this medication to adapt their disease and overcome or prevent complications.

\section{AIM OF THE STUDY}

The present study aims to: Assess effect of direct acting antiviral treatment (sofosbuvir) on daily living activities for patients with hepatitis $\mathrm{C}$ virus.

\section{Research Question:}

What is the effect of direct acting antiviral treatment (Sofosbuvir) on daily living activities of Patients with Hepatitis $\mathrm{C}$ virus?

\section{Operational definition for daily living activity}

Activities of daily living are tasks that are fundamental to supporting participation across school, home and community environments. Activities of daily living are defined as life tasks required for self-care and self-maintenance such as grooming, bathing, eating, and 
doing chores. These tasks are classified as either (1) personal tasks, which are oriented towards self-care (e.g., grooming, bathing); or (2) instrumental tasks, which are oriented towards sustaining independence and require a higher level of physical and cognitive competency than personal (e.g., preparing meals, taking care of pets) (James et al.,2014).

\section{SUBJECTS AND METHOD}

Study design: -A descriptive study design was utilized in the current study.

Study setting: -The study was conducted in hospitals affiliated to Health Insurance which include: El-Mataria Daqahlia Health insurance hospital in El-Mataria city, Daqahlia and EL-Tadamon Hospital in Port -Said city.

Sample size: - Sample size was determined by using the following equation:

\section{$\mathbf{Z}^{2}$}

\section{Sample size $(\mathbf{n})=$}

\section{2 (Dobson. A., 1984)}

\section{Where:}

$\mathbf{n}=$ sample size

$\mathbf{p}=$ The prevalence 0 f patients with viral hepatitis $\mathrm{C}$ in Egypt $=6.3 \%$ (EL-AEL etal, 2017).

$\mathbf{Z}=$ a percentile 0 f the standard n0rmal distributi0n by $95 \%$ c0nfidence level $=1.96$

$\Delta^{2}=$ The width of the confidence interval $=5.0$

$$
\text { Sample size }(\mathbf{n})=\begin{gathered}
1.96^{2} \\
-----------
\end{gathered} 5^{2} \quad 6.3 \times(100-6.3)=90 \text { patients }
$$

Study subjects: -The study was conducted using purposive sample of 100 male and female adult patients who received double and/ or triple therapy of $\mathrm{HCV}$ at least 3 months in the above-mentioned setting was collected during one year.

\section{Tools of data collection: -}

Three tools were used in this study, they are as the following:

Tool 1: -It was developed by the researcher based on reviewing recent related literature (Smeltzer and Bare, 2012). It included two parts:

Part I: - cover patients' demographic data as age, sex, and marital status, job and level of education.

\section{Part II: Medical history}

This part included data related to the following areas:

\section{A- Past Medical History:}


Which include duration of disease, onset of disease, symptoms of disease, presence of chronic disease, drug history, family history of disease, degree of relatives if the disease present, blood transfusion, previous dental procedures anti-bilharzias (tartar) therapy, history of needle stick injuries and/or sharing infected Equipment with $\mathrm{HCV}$, duration of treatment, past hospitalization and prescribed treatment.

\section{B- Past Surgical History:}

History of any surgical operations.

\section{C- Present Medical History:}

Which include the present signs and symptoms related to hepatitis $\mathrm{C}$ virus and/or other complains and adverse effects of the treatment.

\section{Tool 2: Care dependency scale:}

This scale was developed by Dijkstra,Buist and Dassen., (1996). Then, it was translated from English to Arabic and retranslated from arabic to English to ensure stability and clarity. It composed of 15-items that measure the level of caredependency of the following needs: eating and drinking, continence, body posture, mobility, day and night pattern, getting dressed and undressed, body temperature, hygiene, avoidance of danger, communication, contact with others, sense of rules and values, daily activities, recreational activities and learning ability.

\section{Scoring system:}

It is a likert scale rated from 1 to 5 point for each category. Responses range from being ' 1 $=$ completely dependent' to ' $5=$ almost independent'. Persons who fill in the care dependency scale assessed all 15 items by selecting one point from the five-point scale most recently hospital patients with various care needs with a care dependency scale the cutoff point of this scale is 68 which mean the patient get 68 or less was care dependent however, patients get $>68$ was care independent.

\section{Tool (3): Lawton -Brody instrumental activities of daily living scale}

This scale was developed by Graf. (,2008) to assess treatment effects on patient's ability to use telephone, do shopping, food preparation, housekeeping, laundry, use public transportation, be responsible for own medication and to handle finances. The care dependency scale will be translated to Arabic and retranslated to English to ensure its clarity and instability. 


\section{Scoring system:}

A summary score ranges from 0 that mean low function/dependent to 8 that refer to high function/independent for women, and 0 through 5 for men.

\section{Tools Validity:}

Face validity was ascertained by a jury consisting of nine (9) experts in medical and nursing field from faculty of nursing, Port Said University who revised the tools and modifications were done according to their opinion as what.

\section{Reliability:}

\section{Tool 2: Care dependency scale:}

Reliability was determined by Cronbach's a, showing very good results with values of 0.94 and 0.98 . Inter-rater and inter-rater reliability show moderate to substantial Kappa values (Lohrmann et al, 2003).

\section{Tool 3: Lawton -Brody instrumental activities of daily living scal}

Inter-rater reliability was established at 0.85 (try this Best practices in nursing care to older adults, 2008).

\section{Pilot Study:}

A pilot study was conducted on $10 \%$ (ten patients) of the study subjects in the mentioned hospitals to test whether tools of data collection were clear, understandable, and feasible. The results of the data obtained from the pilot study helped the researcher to modify the tools: items were corrected or added as needed and items were deleted. Accordingly, modifications were done and the final form was developed. The patients included in the pilot study were excluded from studied sample.

\section{Field Work:}

The researcher visited the previous mentioned settings and interviewed the responsible nurses and doctors to explain the nature of the study in order to gain their co-operation before data collection. The data were collected over a period of 4 months, the actual field work was carried out from the end of January (2019) to the end of April (2019). The researcher was available two days/week for 5hrs/day. The researcher interviewed the patients, the data collection was performed through meeting patients using the study tools. 
The purpose of the study was explained by the researcher to all patients who were included in the study.

\section{Ethical consideration:}

An approval was taken from ethical committee of faculty of nursing Port Said University. An approval was taken from hospitals administration to conduct the study after explanation of the study aim and process. Patient's verbal consent was obtained before data collection and after explanation of the aim of the study. Anonymity, confidentiality and privacy were asserted. The patients were informed that his or her participation in the study is voluntary and he or she can withdraw at any time.

\section{Statistical design:}

The collected data was organized, revised, computerized, tabulated and analyzed using number and percentage distribution. Statistical analysis was done by computer using Statistical Package of Social Science program (SPSS) package version 18. Proper statistical tests were used to determine whether there was a significant statistical difference between variables of the study. Data was presented in tables and figures. Statistical significance was considered at $\mathrm{P}$-value $<0.05$.

\section{RESULTS:}

Table (1): clarifies that $35 \%$ of study patients their age ranged from $50-60$. However, the mean age of study patients is $52.23 \pm 9.10$ years old. Additionally, $53 \%$ of study patients were males, $84 \%$ had enough income, and $88 \%$ were married. While, $47 \%$ of them got secondary education and $48 \%$ were employee.

Table (2): illustrates that, 53\% of studied sample had triple therapy while $47 \%$ had dual therapy, $97 \%$ of them took therapy for 3 months while $3 \%$ took therapy for 6 months. As regard side effects of hepatitis $\mathrm{C}$ virus therapy, $68 \%$ reported fatigue, $58 \%$ reported body aches, $49 \%$ reported headache, $48 \%$ reported drowsiness, $46 \%$ reported feeling worry, $42 \%$ reported anemia, 33\% reported flu like symptoms, 32\% reported anorexia, 29\% reported nausea or vomiting and $27 \%$ reported insomnia.

Figure (1): shows that the majority of sample $73 \%$ were dependent as an effect of treatment while $27 \%$ were independent.

Table (3): shows scores of IADL among females, the highest percentage of females doing IADL was in the items of ability to use telephone (93.6\%) and the ability to handle finances (93.6\%) followed by $(87.2 \%)$ had the ability of housekeeping, doing laundry 76.6 while the 
lowest percentage was in the items of shopping (21\%) followed by Food preparation $(29.8 \%)$.

Table (4): shows scores of IADL among males, the highest percentage of males doing IADL was in the items of ability to use telephone (98.1\%) followed by Mode of transportation $(92.5 \%)$ and ability to handle finances $(88.7 \%)$ followed by Mode of transportation (67.6\%) while the lowest percentage of males affected doing IADL was in the items of Responsibility for own medications (66.7\%). followed by shopping (66\%).

Table (5): show Relationship between Daily living activities and personal characteristics. It is clarified that there was no significant statistical relationship between Daily living activities and personal characteristics among the studied sample.

Table (1): Distribution of the study patients according to demographic characteristics (number=100)

\begin{tabular}{|c|c|c|c|}
\hline Personal data & Items & No & $\%$ \\
\hline \multirow[t]{6}{*}{ Age (years) } & $21 \leq 31$ & 2 & 2.0 \\
\hline & $31 \leq 41$ & 10 & 10.0 \\
\hline & $41 \leq 51$ & 34 & 34.0 \\
\hline & $51 \leq 61$ & 35 & 35.0 \\
\hline & $61 \leq 71$ & 19 & 19.0 \\
\hline & \multicolumn{3}{|c|}{ Range: $24.0-70.0$ years, Mean $\pm \mathrm{SD}=52.23 \pm 9.10$ years old } \\
\hline \multirow[t]{2}{*}{ Sex } & Males & 53 & 53.0 \\
\hline & Females & 47 & 47.0 \\
\hline \multirow[t]{2}{*}{ Income } & Enough & 84 & 84.0 \\
\hline & Not Enough & 16 & 16.0 \\
\hline \multirow[t]{4}{*}{ Social status } & Single & 2 & 2.0 \\
\hline & Married & 88 & 88.0 \\
\hline & Divorced & 4 & 4.0 \\
\hline & Widow & 6 & 6.0 \\
\hline \multirow[t]{4}{*}{ Education } & Illiterate & 17 & 17.0 \\
\hline & Read / write & 26 & 26.0 \\
\hline & Secondary & 47 & 47.0 \\
\hline & High & 10 & 10.0 \\
\hline \multirow[t]{5}{*}{ Occupation } & Employee & 48 & 48.0 \\
\hline & House wife & 19 & 19.0 \\
\hline & Retired & 8 & 8.0 \\
\hline & Not working & 5 & \\
\hline & Worker & 20 & $\begin{array}{c}5.0 \\
200\end{array}$ \\
\hline
\end{tabular}


Table (2): Distribution of the study patients according to their Present medical history (number=100)

\begin{tabular}{|l|l|c|c|}
\hline Present medical & Items & No & \% \\
\hline history & & 47 & 47.0 \\
\hline Dype of treatment & Dual therapy & 53 & 53.0 \\
\hline treatment & Triple therapy & 97 & 97.0 \\
\hline Complain from & 3 months & 3 & 3.0 \\
Side effects & 6 months & 32 & 32.0 \\
& - -Fatigue & 68 & 68.0 \\
& -Nausea / vomiting & 29 & 29.0 \\
& -Diarrhea & 58 & 58.0 \\
& - Muscles aches & 42 & 42.0 \\
& -Constipation & 29 & 29.0 \\
& - Mouth sore & 27 & 27.0 \\
& -Insomnia & 48 & 48.0 \\
& -Drowsiness & 49 & 49.0 \\
& -headache & 46 & 46.0 \\
& -Tachycardia & 25 & 25.0 \\
& -Poor concentration & 33 & 33.0 \\
& -Flu like symptoms & & 18.0 \\
& -Teeth aches & & \\
\hline
\end{tabular}

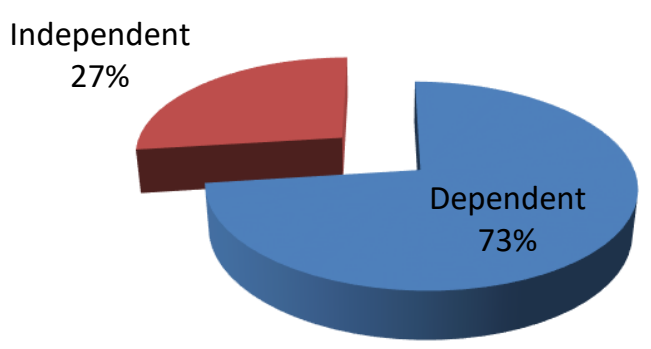

Figure (1): Percent of dependency in the studied group 
Table (3): Scores of LADL among females (47)

\begin{tabular}{|c|c|c|c|}
\hline Activities & Scores & No & $\%$ \\
\hline $\begin{array}{l}\text { A. Ability to use } \\
\text { telephone }\end{array}$ & $\begin{array}{l}0 \\
1\end{array}$ & $\begin{array}{c}3 \\
44\end{array}$ & $\begin{array}{c}6.4 \\
93.6\end{array}$ \\
\hline B. Shopping & $\begin{array}{l}0 \\
1\end{array}$ & $\begin{array}{l}37 \\
13\end{array}$ & $\begin{array}{l}78.7 \\
21.3\end{array}$ \\
\hline C. Food preparation & $\begin{array}{l}0 \\
1\end{array}$ & $\begin{array}{l}33 \\
14\end{array}$ & $\begin{array}{l}70.2 \\
29.8\end{array}$ \\
\hline D. House keeping & $\begin{array}{l}0 \\
1\end{array}$ & $\begin{array}{c}6 \\
41\end{array}$ & $\begin{array}{l}12.8 \\
87.2\end{array}$ \\
\hline E. Laundry & $\begin{array}{l}0 \\
1\end{array}$ & $\begin{array}{l}11 \\
36\end{array}$ & $\begin{array}{l}23.4 \\
76.6\end{array}$ \\
\hline $\begin{array}{l}\text { F. Mode of } \\
\text { transportation }\end{array}$ & $\begin{array}{l}0 \\
1\end{array}$ & $\begin{array}{c}9 \\
38\end{array}$ & $\begin{array}{l}19.1 \\
80.9\end{array}$ \\
\hline $\begin{array}{l}\text { G. Responsibility for } \\
\text { own medications }\end{array}$ & $\begin{array}{l}0 \\
1\end{array}$ & $\begin{array}{l}18 \\
21\end{array}$ & $\begin{array}{l}38.3 \\
61.7\end{array}$ \\
\hline $\begin{array}{l}\text { H. Ability to handle } \\
\text { finances }\end{array}$ & $\begin{array}{l}0 \\
1 \\
\end{array}$ & $\begin{array}{c}3 \\
44 \\
\end{array}$ & $\begin{array}{c}6.4 \\
93.6 \\
\end{array}$ \\
\hline Total Score & $\begin{array}{c}\text { Range } \\
\text { Mean } \pm \text { SD }\end{array}$ & \multicolumn{2}{|c|}{$\begin{array}{c}0.0-8.0 \\
5.50 \pm 1.65\end{array}$} \\
\hline Total percent score & $\begin{array}{c}\text { Range } \\
\text { Mean } \pm \text { SD }\end{array}$ & \multicolumn{2}{|c|}{$\begin{array}{c}0.0-100.0 \\
68.62 \pm 20.67\end{array}$} \\
\hline
\end{tabular}

Table (4): Scores of LADL among males (53)

\begin{tabular}{|l|c|c|c|}
\hline Activities & Scores & No & \% \\
\hline A. Ability to use & 0 & 1 & 1.9 \\
telephone & 1 & 52 & 98.1 \\
\hline B. Shopping & 0 & 18 & 34.0 \\
& 1 & 35 & 66.0 \\
\hline F. Mode of & 0 & 4 & 7.5 \\
transportation & 1 & 49 & 92.5 \\
\hline G. Responsibility for & 0 & 17 & 32.1 \\
own medications & 1 & 36 & 67.9 \\
\hline H. Ability to handle & 0 & 6 & 88.7 \\
finances & 1 & 47 & $01.0-5.0$ \\
\hline Total Score & Range & \multicolumn{2}{|c|}{$20.0-100.0$} \\
& Mean \pm SD & Range & \multicolumn{2}{|c|}{$83.02 \pm 24.93$} \\
\hline Total percent score & Mean \pm SD & \multicolumn{2}{|c|}{} \\
\end{tabular}


Table (5): Relation between Daily living activities and personal characteristics of the studied patients (100).

\begin{tabular}{|l|l|c|c|c|}
\hline \multicolumn{1}{c|}{$\begin{array}{c}\text { Personal } \\
\text { data }\end{array}$} & \multicolumn{1}{|c|}{ Items } & No & $\begin{array}{c}\text { Daily living } \\
\text { activities }\end{array}$ & Significance test \\
\cline { 3 - 4 } & & & Mean \pm SD & \\
\hline Age (years) & & & $4.83 \pm 1.63$ & $\mathrm{r}=0.352$ \\
& & & & $\mathrm{P} 0.000$ \\
\hline Sex & Males & 53 & $4.24 \pm 1.39$ & $\mathrm{t}=4.075$ \\
& Females & 47 & $5.48 \pm 1.65$ & $\mathrm{P} 0.000$ \\
& & & & \\
\hline Income & Moderate & 84 & $4.7 \pm 1.55$ & $\mathrm{t}=0.617$ \\
& Above moderate & 16 & $5.06 . \pm 2.08$ & $\mathrm{P} 0.539$ \\
\hline Social status & Single & 2 & $1.50 \pm 71$ & $\mathrm{~F}=7.058$ \\
& Married & 88 & $4.90 \pm 1.51$ & $\mathrm{P} 0.000$ \\
& Divorced & 4 & $6.75 \pm .96$ & \\
& Widow & 6 & $3.50 \pm 1.76$ & \\
\hline Education & Illiterate & 17 & $4.58 \pm 1.58$ & $\mathrm{~F}=.0 .167$ \\
& Read / write & 26 & $4.88 \pm 1.84$ & $\mathrm{P} 0.918$ \\
& Secondary & 47 & $4.85 \pm 1.50$ & \\
& High & 10 & $5.00 \pm 2.00$ & \\
\hline Occupation & Employee & 48 & $5.04 \pm 1.69$ & $\mathrm{~F}=1.303$ \\
& House wife & 19 & $5.21 \pm 1.51$ & $\mathrm{P} 0.269$ \\
& Retired & 8 & $4.125 \pm 1.46$ & \\
& Not working & 5 & $4.20 \pm 2.49$ & \\
& Worker & 20 & $4.28 \pm 1.41$ & \\
\hline
\end{tabular}

$\mathrm{t}=$ independent test, $\mathrm{F}=\mathrm{ANOVA}$. $\mathrm{r}=$ Pearson correlation, Statistical significance at $\mathrm{p} \leq 0.05$

\section{DISCUSSION:}

Infection with the hepatitis $\mathrm{C}$ virus (HCV) remains a major health problem, and the patients with hepatitis $\mathrm{C}$ virus necessitate to change their lifestyle and adopt healthy behaviors through adjustment to a chronic medical condition, managing of symptoms and treatment health consequences, and making and maintain lifestyle changes (Abd ElMaksoud, et al,2015)

the present study assessed socio-demographic data of the study sample, the result showed that, most of the HCV patients aged between 40- 60 years old and most of the studied sample were males. This is common finding in Egypt where Abdel salam (2016) who conduct a study about daily living among patients with chronic Hepatitis C Virus. Moreover, this study finding goes in the same line with Juanbeltz et al. (2018) who conduct a study about impact of successful treatment with direct-acting antiviral agents which found 
that the mean age of the $\mathrm{HCV}$ patients was 52.3 years and nearly two thirds of them were males.

Regarding the educational level of the study sample, the present study revealed that, nearly about half of the studied sample had secondary education and the minority of the HCV patients were has a university education. In agreement with this finding, Rezik (2012) who conduct a study about Assessing knowledge for patients with chronic viral hepatitis c in Egypt and reported that, the minority of the HCV patients were have a university education. However, this finding was in disagreement with El Malky et al., (2016) who mentioned that four fifth of the HCV patients were highly educated.

from the researcher point of view, it should be noted that, the educational level may affect the patient's ability to cope with their own health problems. Low educated patients are prone to have more health problems because they have false beliefs and false health practice as re-use the syringes. Additionally, illiteracy leads to lake of information about the disease, how to overcome complications, and affect patient's compliance with the treatment regimen.

In relation to marital status, nearly all the studied sample were married, this result is supported by Abdel salam (2016). The researcher returns these finding to the same age groups of the studied sample. Concerning income, the majority of the studied sample had moderate income, on the same line, Rizk (2015) who conduct a study in Egypt about the impact of educational program on quality of life in Hepatitis $\mathrm{C}$ infected patients and emphasizes the same result.

Regarding treatment protocol, less than half of HCV patients used Sofo and Dacla and more than half used Sofo, Dacla and Riba. Nearly all the patient had treatment for three months. Patients received treatment according to the Egyptian national committee of viral hepatitis recommendations and according to the availability of the drugs in the centers. This result goes in agreement with Attia et al., (2018) in the study about the adverse effects of interferon-free regimens in chronic hepatitis $\mathrm{C}$ treated Egyptian patients.

Another important objective of the present study was to asses treatment side effects, the present study revealed that, more than two thirds of the studied sample suffering from fatigue, more than half of the participants suffering from myalgia while less than half of them suffering from headache. This finding was supported by Abd- Elsalam et al., (2018) in his study about efficacy and safety of sofosbuvir plus ribavirin for treatment of cirrhotic patients which found that the most common adverse events were fatigue, myalgia, 
headache, insomnia, and anemia. Nonetheless, Evon et al., (2018) in a study about a comprehensive assessment patient initiating direct acting antiviral therapy for chronic hepatitis $\mathrm{C}$ and reported that, Pain, fatigue, and sleep disturbance were common and often severe. This result may be due to using ribavirin as a component of sovaldi combination therapy; ribavirin has many side effects include anemia, fatigue and headache.

Contradictory, this finding disagreed with Ahmed et al., (2018) in their study about sofosbuvir plus daclatasvir in treatment of chronic hepatitis $\mathrm{C}$ Egyptian patients and reported that treatment have no notable adverse events.

Interestingly, this study revealed that about three fourths of the studied sample were dependent, while more than one- fourth were independent. The majority of sample were nearly dependent in personal ADL, (self-care activities as continence, getting dressed and undressed, body temperature, communication and Day and night pattern). The majority of sample not affected( partially dependant ) in all physical activities like bathing, dressing, toileting or feeding, while about one fourth one- fourth were dependent in other activities which need more effort or more cognitive abilities as walking, shopping, working , housekeeping, contact with others, learning ability or recreational activities. This finding agrees with Abdel salam (2016) in the study about Activities of daily living among patients with chronic Hepatitis $\mathrm{C}$ which mentioned that the majority of sample were independent in personal ADL, but only one-third were independent according to instrumental ADL and had no limitation related to social/lifestyle activities.

Concerning the components of the IADL, high percentage of the studied sample had difficulty in shopping, food preparation and responsibility for own medications. Moreover, nearly fourth of the studied sample had difficulty in the item of laundry. Additionally, high percentage of the studied population did not have difficulty in the items of using telephone, handling medications, handling finances and using transportation.

This finding agrees with Juanbeltz et al. (2019) in the study about health-related quality of life in hepatitis $\mathrm{C}$ patients who achieve sustained virological response to directacting antivirals, Spain and revealed that HRQoL of chronic hepatitis $\mathrm{C}$ patients remains lower than that of the general population despite viral clearance, with primary problems in usual activities and anxiety/depression.

As regard to every day work (shopping, working, food preparation, laundry and housekeeping), the majority of the studied sample was affected sometimes cut down the amount of time spent in work and other activities, having difficulty in performing work and 
it took extra effort. This finding is consistent with the finding of Dowsett et al., (2017) in the study living with hepatitis $\mathrm{C}$ virus which revealed that broadly, studies reported that participants experienced considerable disruption to daily living, impaired quality of life, and chronic physical and psychological symptoms related to HCV

As regard to social activities, the greatest decrements observed in social functioning by depending on others in starting, keeping and finishing social relation as fatigue also impact on social live and created interpersonal strains among family and friends. According to El-Gendi 2018 in a study about impact of structured nursing protocol on minimizing selected side effects of Sovaldi in Egypt highlight the voice of family members who were negatively impacted with fatigue in the study.

As regard to Learning ability and recreational activities, the majority of the studied sample was affected, these findings supported by Zalai et at. (2016) in the study about fatigue in chronic hepatitis $\mathrm{C}$ infection who have written that fatigue among patient with chronic HCV infection experienced cognitive and behavioral deficits.

From the current study finding, it is cleared that this decrease in ability of performing activities of daily living was observed at first month of the treatment compared to the other evaluated weeks and after completing treatment. This decrease followed by improvement in daily living after week 4 and after SVR. This finding agrees with Younossi et al.2016 in the study about association of work productivity with clinical and patient reported factors in patients infected with hepatitis $\mathrm{c}$ virus which revealed that a significant decline in quality of life was observed in majority of sample in some domains, including physical and social functioning at week 4 of active treatment with DAAs therapy.

In the current study, there were no significant statistical relation between activities of daily living and demographic data.This finding agrees with Mohamed (2016) in the study about treatment Response of Chronic Hepatitis C Patients in Egypt which revealed that chronic HCV patients with chronic diseases were significantly associated with poor HRQOL in the domains of physical functioning, role limitations due to physical health problems, role limitations due to emotional problems and pain .

\section{CONCLUSION}

Based on the findings of the current study, the majority of sample were nearly independent in personal ADL and in physical activities. while about one fourth of sample were dependent in other activities which need more effort or more cognitive abilities. On 
the other hand, there were no significant statistical relation between activities of daily living and personal characteristics as age or sex.

\section{RECOMMENDATIONS}

In the light of the study results, the following recommendations are proposed:

- Develop a health education unit in each specialized liver centers with a qualified and trained nurse available all time. In addition, weekly meeting should be organized for patients counseling and health problem solving.

- Assessment of patient physical, psychological, social and spiritual health behaviors should be a part of routine patient's health assessment.

- Design patient educational materials to present more comprehensive information. A colored booklet containing relevant information and simple figures about healthy behaviors of HCV patients treated by combination therapy should be available in all hospitals and should be given to all newly admitted patients. Itshould be adapted to every patient's individual needs related to the line of treatment.

- Further study is recommended in a larger sample with considering factors could affecting patient's response to viral hepatitis treatment.

\section{REFERENCES}

AbdEllatef, M. A. B., \& Mohamed, A, T., (2019): Effect of Health Education program on Life Style of Patients with Hepatitis C Virus Receiving Sovaldi Combination Therapy. Vol. 6, Issue 1, pp: 933-943

Abdel salam,E.,F,.A.,(2016):Activities of daily living among patients with chronic HepatitisC Virus. Published master thesis. Ain Shams Uni;Fac. Nursing ,Pp38-45

Abd-Elsalam, S., Sharaf-Eldin, M., Soliman, S., Elfert, A., Badawi, R., \& Ahmad, Y. K. (2018): Efficacy and safety of sofosbuvir plus ribavirin for treatment of cirrhotic patients with genotype 4 hepatitis $\mathrm{C}$ virus in real-life clinical practice. Archives of virology, 163(1), 51-56.

Ahmed, M. (2018). Era of direct acting anti-viral agents for the treatment of hepatitis C. World journal of hepatology, 10(10), 670. 
Attia, D., El Saeed, K., Elakel, W., El Baz, T., Omar, A., Yosry, A., ... \& Doss, W. (2018): The adverse effects of interferon-free regimens in 149816 chronic hepatitis C treated Egyptian patients. Alimentary Pharmacology \& Therapeutics, 47(9), 1296-1305.

Crusse, E. P., \& Kent, V. P. (2015): Get the facts: Hepatitis C. Nursing made Incredibly Easy, 13(5), 40-49.

Dijkstra, A., Buist, G., \& Dassen, T. (1996): Nursing-care dependency: development of an assessment scale for demented and mentally handicapped patients. Scandinavian Journal of Caring Sciences, 10(3), 137-143.

Dowsett, L. E., Coward, S., Lorenzetti, D. L., MacKean, G., \& Clement, F. (2017): Living with hepatitis $C$ virus: a systematic review and narrative synthesis of qualitative literature. Canadian Journal of Gastroenterology and Hepatology, 2017.

Dusheiko, G. (2017). The impact of antiviral therapy for hepatitis C on the quality of life: a perspective. Liver International, 37, 7-12.

El-Gendi,S.,M.,(2018):Impact of structured nursing protocol on minimizing selected side effects of Sovaldi among hepatitis c virus patients at Kafer El-sheikh liver institute . Published doctolalr thesis. Mansoura Uni;Fac. Nursing ,Pp49-54.

El Malky, M. E., Gahsh, N. E., \& Atia, M. M. (2016): The effectiveness of nursing intervention program on emotional distress, self-efficacy, and liver enzymes among hepatitis $\mathrm{C}$ virus patients undergoing antiviral treatment therapy (sovaldi medication). American Journal of Nursing, 5(3), 72-84.

El-Maksoud, M. M. A., El-Mohsen, A. S. A., Talhat, T., \& Abdalla, N. (2015): Nursing Intervention for Changing the Lifestyle of Chronic Hepatitis C. journal of Nursing and Health Science; 4(4), 75-83.

Evon, D. M., Stewart, P. W., Amador, J., Serper, M., Lok, A. S., Sterling, R. K., ... \& Reau, N. (2018): A comprehensive assessment of patient reported symptom burden, medical comorbidities, and functional well being in patients initiating direct acting antiviral therapy for chronic hepatitis C: Results from a large US multi-center observational study. PloS one, 13(8), e0196908.

Graf, C. (2008). The Lawton instrumental activities of daily living scale. AJN The American Journal of Nursing, 108(4), 52-62. 
Ioannou, G. N., Green, P. K., Beste, L. A., Mun, E. J., Kerr, K. F., \& Berry, K. (2018): Development of models estimating the risk of hepatocellular carcinoma after antiviral treatment for hepatitis C. Journal of hepatology, 69(5), 1088-1098.

James, S., Ziviani, J., \& Boyd, R. (2014): A systematic review of activities of daily living measures for children and adolescents with cerebral palsy. Developmental Medicine \& Child Neurology, 56(3), 233-244.

Juanbeltz, R., Martínez-Baz, I., San Miguel, R., Goñi-Esarte, S., Cabasés, J. M., \& Castilla, J. (2018): Impact of successful treatment with direct-acting antiviral agents on health-related quality of life in chronic hepatitis C patients. PloS one, 13(10), e0205277.

Juanbeltz, R., Castilla, J., Martínez-Baz, I., O'Leary, A., Sarobe, M., \& San, R. M. (2019). Health-related quality of life in hepatitis C patients who achieve sustained virological response to direct-acting antivirals: a comparison with the general population. Quality of life research: an international journal of quality of life aspects of treatment, care and rehabilitation, 28(6), 1477-1484.

Kesen, O., Kani, H. T., Yanartaş, Ö., Aykut, U. E., Gök, B., Gündüz, F., ... \& Alahdab, Y. Ö. (2019). Evaluation of depression, anxiety and quality of life in hepatitis C patients who treated with direct acting antiviral agents. The Turkish Journal of Gastroenterology, 30(9), 801.

Lohrmann, C., Dijkstra, A., \& Dassen, T. (2003): Care dependency: testing the German version of the care dependency scale in nursing homes and on geriatric wards. Scandinavian Journal of Caring Sciences, 17(1), 51-56.

Mohamed, D., Hasab, A., El-Hassafy, M., \& El-Nimr, N. (2016): Treatment Response of Chronic Hepatitis C Patients and Health-Related Quality of Life. Journal of High Institute of Public Health, 46(1), 15-24.

Rezik, S, (2012): assessment knowledge for patients with chronic hepatitis (c) receiving interferon therapy, Published master thesis, medical-surgical nursing, faculty of nursing, Benha University. P.p (79-84)10.

Rizk, S., M., A., (2015). Impact of educational program on quality of life in Hepatitis $\mathrm{C}$ infected patients treated by pegylated interferon and ribavirin. Published Doctoral thesis .Port Said Uni;Fac. Nursing,Pp. 
Smeltzer S.,C., \&Bare B.,G., (2013): Bruner and Saddarth's text Book of Medical Surgical Nursing, 13th ed., Lippincott Williams Philadelphia Co., U.S.A., P.p. 1075, 1101 1113.)

Tawfeek, G. A., El-Deib, A. E. R., Attia, F. M., El-Nemr, N., Faisal, A. S., \& Faisal, A. S. (2020): Evaluating the Effects of Anti-Viral Therapy on Insulin Resistance and Diabetic Status in Chronic Hepatitis C patients. Afro-Egyptian Journal of Infectious and Endemic Diseases, 10(3), 287-293.

Younossi, Z. M., Stepanova, M., Esteban, R., Jacobson, I., Zeuzem, S., Sulkowski, M., ... \& Hunt, S. (2017). Superiority of interferon-free regimens for chronic hepatitis C: the effect on health-related quality of life and work productivity. Medicine, 96(7)5914.

Zalai, D., Carney, C. E., Sherman, M., Shapiro, C. M., \& McShane, K. (2016). Fatigue in chronic hepatitis $\mathrm{C}$ infection: Understanding patients' experience from a cognitive-behavioural perspective. British journal of health psychology, 21(1), 157-172.

Zwakhalen, S. M., Hamers, J. P., Metzelthin, S. F., Ettema, R., Heinen, M., de ManVan Ginkel, J. M., ... \& Schuurmans, M. J. (2018): Basic nursing care: The most provided, the least evidence based-A discussion paper. Journal of clinical nursing, 27(11-12), 24962505 . 
أثثار مضادات الفيروسات ذات المفعول المباثر (السوفوسبيوفير) على أنثطة الحياة اليومية لمرضى الالتهاب الكبدي الفيروسي سي

هاى محمود سليمان -أ.د /إيمان صالح شاهين - م/ أماني جمال الغريب

بكالوريوس التمريض ـكلية التمريض- جامعة الدنصورة ـ استاذ تمريض الباطني والجراحي مدرس تمريض الباطني والجر/حي

\section{الخلاصة}

يؤثر الالتهاب الكبدي الفيروسي سي على أنشطة الحياة اليومية. ولقد أظهرت مضادات الفيروسات ذات المفعول

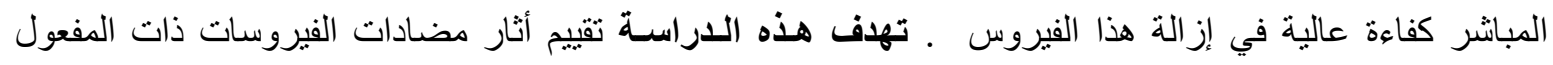
المباشر على أنشطة الحياة اليومية لمرضى الالتهاب الكبدي الفيروسي سي. وقد استخدمت هذه الدراسة الوصفية العينة

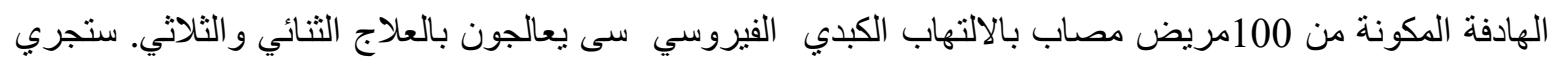
الدراسة في مستثفى التضامن ببورسعيد ومستثفى التنامين الصحي بمدينة المطرية بمحافظة الدقهلية. وقد تم استخدام

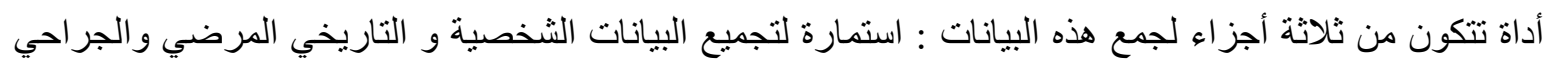

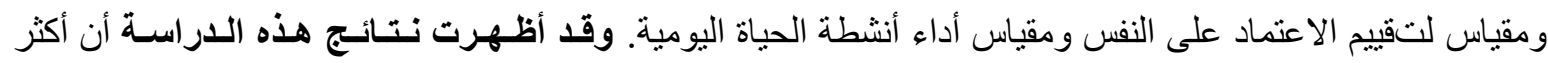

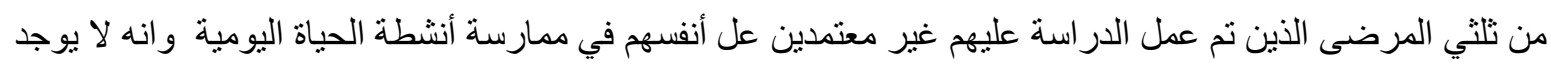

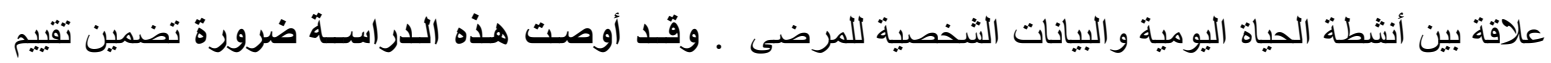

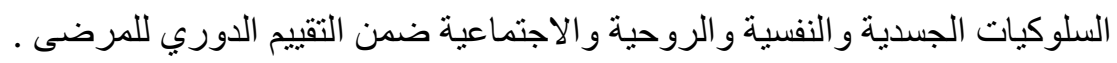

الكلمات المرشدة : الالتهاب الكبدي الفيروسي سي ،مضادات الفيروسات ذات المفعول المباشر ، أنثطة الحياة اليومية

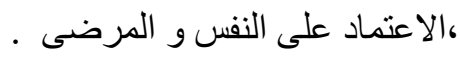

